\title{
Leguminous Alley Cropping Improves the Production, Nutrition, and Yield of Forage Sorghum
}

\author{
Robson da Costa Leite ${ }^{1, *} \mathbb{( D}$, José Geraldo Donizetti dos Santos ${ }^{2}$, Rubson da Costa Leite ${ }^{1}$, \\ Luciano Fernandes Sousa ${ }^{2}$, Guilherme Octávio de Sousa Soares ${ }^{3}$, Luan Fernandes Rodrigues ${ }^{2}$, \\ Jefferson Santana da Silva Carneiro ${ }^{4}\left(\mathbb{D}\right.$ and Antonio Clementino dos Santos ${ }^{2}$ \\ 1 Institute of Agricultural Sciences, Federal Rural University of Amazon (ICA-UFRA), Belém 66077-530, Pará, \\ Brazil; rubsonif@gmail.com \\ 2 School of Veterinary Medicine and Animal Science, Federal University of Tocantins, Araguaina 77804-970, \\ Tocantins, Brazil; jgsanttos@gmail.com (J.G.D.d.S.); luciano.sousa@mail.uft.edu.br (L.F.S.); \\ luanfr@gmail.com (L.F.R.); clementino@mail.uft.edu.br (A.C.d.S.) \\ 3 Federal Institute of Education, Science, and Technology of Tocantins, Araguatins 77950-000, Tocantins, Brazil; \\ guilhermeoctavio21@hotmail.com \\ 4 Soil Science Department, Federal University of Lavras 37200-000, Minas Gerais, Brazil; \\ carneirojss@yahoo.com.br \\ * Correspondence: robsontec.agrop@gmail.com; Tel.: +55-(63)-99988-4434
}

Received: 24 July 2019; Accepted: 9 October 2019; Published: 14 October 2019

\begin{abstract}
This study aimed to evaluate the growth, production, and leaf contents of macronutrients, as well as the yield of forage sorghum cultivated on the alleys of Gliricidia (Gliricidia sepium (Jacq.) Kunth ex Walp.) and Leucaena (Leucaena leucocephala (Lam.) de Wit) in the presence and absence of mineral fertilization. The experiment was conducted in two different periods: During the 2016/2017 double crop (cultivation carried out at the end of the crop cycle) and during the 2017/2018 crop (cultivation carried out at the beginning of the crop cycle). A randomized block design, in which the first factor refers to cultivation systems (single sorghum, sorghum cultivated in Gliricidia alleys, and sorghum cultivated in Leucaena alleys) and the second factor refers to mineral fertilization (presence and absence of fertilization), in a $3 \times 2$ factorial arrangement was used. The leguminous plants were cut, and the residues were deposited in the alleys. The cultivation in alleys without mineral fertilization increased total forage biomass when compared to the single crop cultivation. Cultivation in Leucaena alleys showed a higher leaf content of nitrogen $(\mathrm{N})$ when compared to the single crop, both in the presence and absence of mineral fertilization. In the double crop, sorghum cultivated in Leucaena alleys without fertilization presented a higher forage yield (up to 67\%) when compared to the single crop system. However, there was no difference in yield when mineral fertilization was applied to the treatments. Overall, the alley crops were able to increase the morphological (plant height $(\mathrm{PH})$, stem diameter (SD), panicle diameter (PD), and panicle length (PL) and yield (leaf dry mass (LDM), stem dry mass (SDM), total green mass (TGM), and total dry mass TDM) variables of the crop, improving the productivity of forage sorghum.
\end{abstract}

Keywords: cultivation systems; Gliricidia sepium; leguminous plants; Leucaena leucocephala; mineral fertilization

\section{Introduction}

Overall, about 70\% of Brazilian soils are represented by Oxisols, Ultisols and Entisols, which are soil classes of predominantly low fertility. Thus, agricultural production might be restricted if there is no nutrient addition to the soil [1]. Mineral fertilizers are often the first choice used to improve the chemical properties of soil [2,3]. However, organic materials such as plant residues can also 
play an important role in the improvement of tropical agriculture systems. After decomposition, the organic materials provide nutrients and substrate for the synthesis of organic matter in the soil [4]. The chemical, physical, and biological properties of soils can be greatly improved using alley cropping, which represents an accessible option for the addition of organic matter to the soil [2].

Alley cropping involves the cultivation of annual crops among the hedgerows of multipurpose trees. Plant residues from the leguminous trees can be used as organic fertilizers, promoting improvements in soil fertility $[5,6]$. The benefits of this system of production include surface cover with plant residues, nutrient recycling, the biological fixation of atmospheric nitrogen (BNF), and the increase of the bearing capacity of the soil [7-9].

Alley cropping is a viable option to increase biomass production per unit area. Since the plant residues can be incorporated into the soil, the transference of nutrients from trees to annual crops can also occur [8]. Furthermore, since the leguminous crops used in alleys present a deep root system, the interception of percolated nutrients along the soil profile can occur, and nutrients accumulated in layers below the root zone of annual crops can be accessed. These nutrients absorbed by the root system of the trees become inputs when transferred to the soil surface in the form of litter and other plant residues [10].

Leguminous alleys disposed in annual crops represent relevant $\mathrm{N}$ inputs by biological fixation, reducing the need for $\mathrm{N}$ fertilization. For example, Leucaena (Leucaena leucocephala (Lam.) de Wit.) and acacia (Acacia Mangium montanum Rumph.) arranged in maize (Zea mays (L.) alleys produced large amounts of $\mathrm{N}$ due to the increase of biomass and soil fixation [11]. There is evidence that maize cultivated in Gliricidia (Gliricidia sepium (Jacq.) Kunth ex Walp.) alleys increase their foliar N content by up to $5 \mathrm{~g} \mathrm{~kg}^{-1}$ when compared to single maize cultivation with mineral fertilization [12]. Legumes produce organic matter of greater bioavailability, which can also increase the cation exchange capacity (CEC) of sandy soils [13].

Among the trees and shrubs used in alley cropping systems, Gliricidia is widely used in the Brazilian northeast $[5,8,14]$. Leucaena is also common in alley cultivation. Though Leucaena has a higher competitive effect when compared to Gliricidia, it produces higher amounts of residues [11-15]. These species are widely used both in the incorporation of biomass into the soil and in animal feeding, and they are usually cut two to three times per year [5]. Furthermore, they are considered drought-resistant species that produce large amounts of biomass with high $\mathrm{N}$ levels and fast decomposition rates [16]. However, only a few scientific studies have thus far focused on the cultivation of forage sorghum (Sorghum bicolor (L.) Moench) in leguminous alleys, especially in areas of livestock activity $[17,18]$.

Forage sorghum belongs to the Poaceae family, and it is among the most cultivated species in the world. Sorghum is widely used by farmers for forage production due to its high percentage of leaf and stem production when compared to other plant species. There are two categories of sorghum: Specific cultivars for grain production and specific cultivars for forage production [18]. Therefore, its high drought adaptability, high dry mass yield, and high nutrient recycling capacity make this crop attractive for forage production [13].

Agricultural crops, especially annual crops, require adequate fertility levels for their development. Therefore, the adoption of leguminous alleys in forage sorghum cultivation for sustainable soil fertility management represents a great option for nutrient input, especially for resource-poor farmers [2].

The present study was based on the hypothesis that the presence of leguminous alleys in forage sorghum cultivation would promote greater growth and development, as well as higher foliar macronutrient contents and productivity, thus making alley cropping superior to the cultivation of single sorghum. Therefore, the objective of this study was to evaluate forage sorghum cultivation using a combination of leguminous alleys and mineral fertilization. 


\section{Materials and Methods}

\subsection{Experimental Area and Treatments}

Two field experiments were conducted at the School of Veterinary and Animal Science of the Federal University of Tocantins (810751.01; 9213652.69 UTM, with an altitude of $243 \mathrm{~m}$ ), Brazil. The first experiment was implemented in the agricultural year 2016/2017 and the second in 2017/2018. This region is classified as warm and humid (AW type according to the Köppen classification). The area presents two growing seasons: A dry period with a water deficit from May to September and a rainy period between October and April [19]. The rainfall and the average temperature throughout the experimental period are shown in Figure 1.

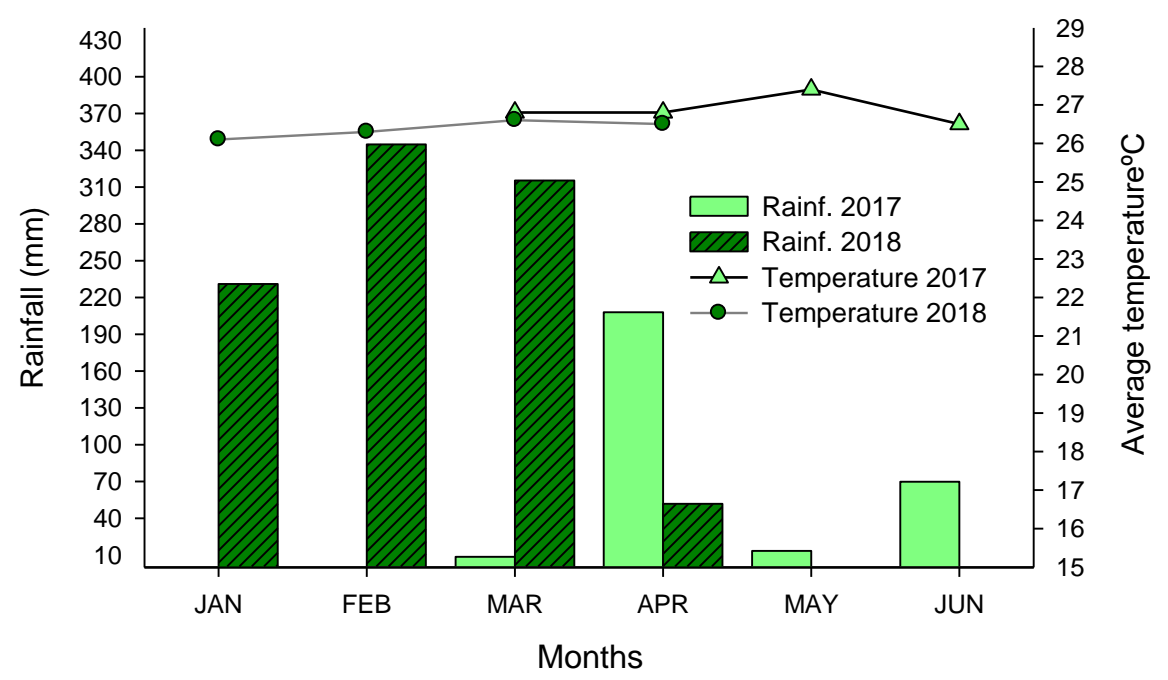

Figure 1. Average monthly rainfall and temperature for the experimental site during the 2016-2018 growing season.

Table 1 shows the physical and chemical attributes of the soil prior to the cultivation of the first crop cycle. The soil is classified as Entisol (quartzipsamment) [1].

Table 1. Data from chemical and physical analysis of the soil in preplant in the experimental site (0.00-0.20 m layer).

\begin{tabular}{lc}
\hline \multicolumn{1}{c}{ Attribute } \\
\hline $\mathrm{pH}\left(\mathrm{H}_{2} \mathrm{O}\right)$ & 5.3 \\
Organic matter $\left(\mathrm{g} \mathrm{kg}^{-1}\right)$ & 6.0 \\
Available P $\left(\mathrm{mg} \mathrm{dm}^{-3}\right)$ & 7.48 \\
Available K $\left(\mathrm{mg} \mathrm{dm}^{-3}\right)$ & 8.0 \\
$\mathrm{Ca}^{2+}\left(\mathrm{cmol}_{\mathrm{c}} \mathrm{dm}^{-3}\right)$ & 2.47 \\
$\mathrm{Mg}^{2+}\left(\mathrm{cmol}_{\mathrm{c}} \mathrm{dm}^{-3}\right)$ & 1.19 \\
$\mathrm{Al}^{3+}\left(\mathrm{cmol}_{\mathrm{c}} \mathrm{dm}^{-3}\right)$ & 0.04 \\
$\mathrm{H}^{+}+\mathrm{Al}^{3+}\left(\mathrm{cmol}_{\mathrm{c}} \mathrm{dm}^{-3}\right)$ & 1.78 \\
$\mathrm{CEC}_{\left(\mathrm{cmol}_{\mathrm{c}} \mathrm{dm}^{-3}\right)}$ & 5.46 \\
Sand $\left(\mathrm{g} \mathrm{kg}^{-1}\right)$ & 893.5 \\
Silt $\left(\mathrm{g} \mathrm{kg}^{-1}\right)$ & 6.5 \\
Clay $\left(\mathrm{g} \mathrm{kg}^{-1}\right)$ & 100.0 \\
\hline
\end{tabular}

$\mathrm{pH}\left(\mathrm{H}_{2} \mathrm{O}\right)$ at a ratio of 1:2.5 m/v; organic matter determined by the Walkley-Black method; available P e K: Mehlich-1 extraction; exchangeable $\mathrm{Ca}, \mathrm{Mg}$ and $\mathrm{Al}$ : Extraction with $\mathrm{KCl} ; \mathrm{H}+\mathrm{Al}$ : Extraction with calcium acetate; clay content: The pipette method.

The experiment followed a randomized block design with a factorial arrangement of $3 \times 2$ and five replications. The first factor refers to the cultivation system (single sorghum, sorghum cultivated 
in Gliricidia alleys, and sorghum cultivated in Leucaena alleys), and the second factor refers to mineral fertilization (the presence and absence of fertilization) (Figure 2). The total area of the experiment was $900 \mathrm{~m}^{2}$, and each experimental unit had a total area of $30 \mathrm{~m}^{2}(6 \times 5 \mathrm{~m})$.
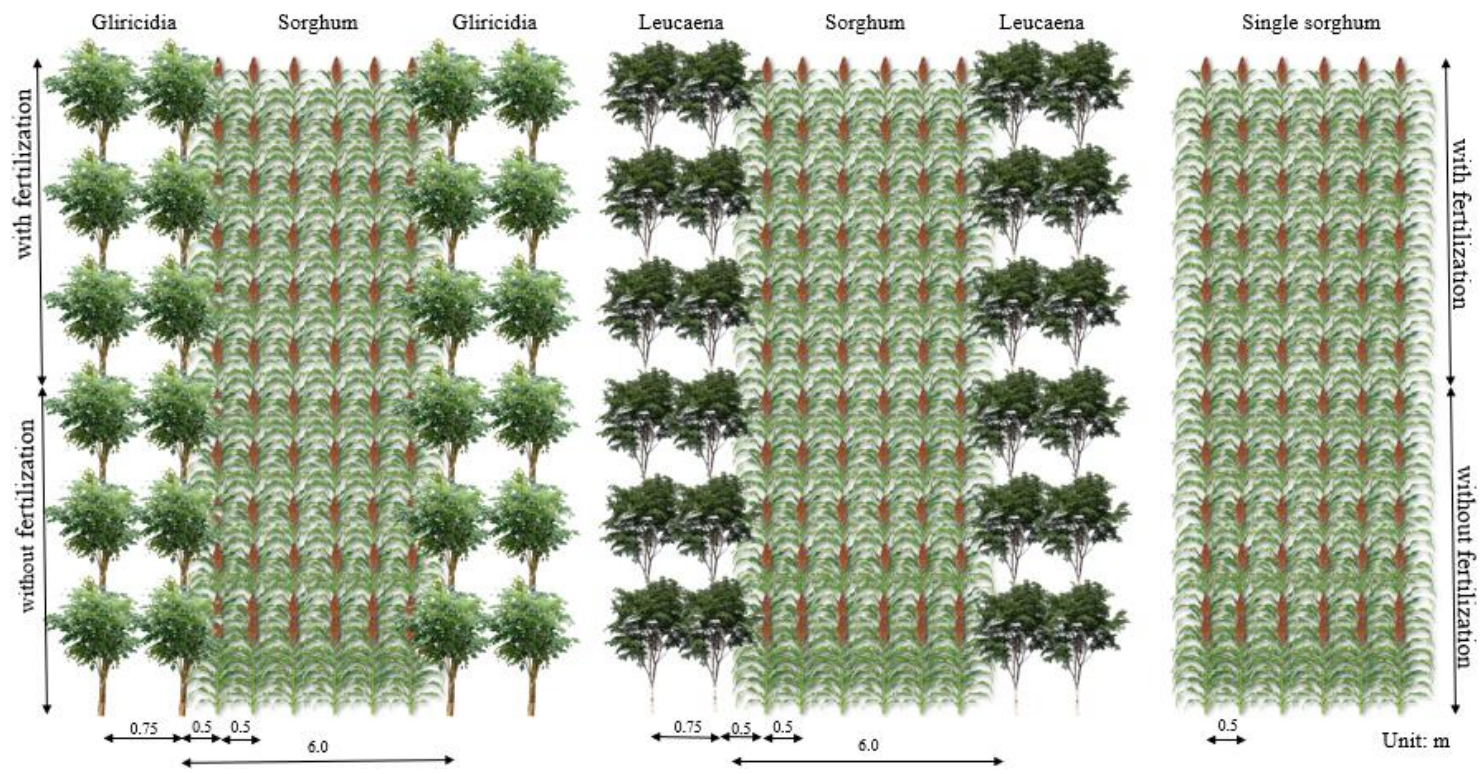

Figure 2. Scheme of the arrangement of cultivation systems and mineral fertilization in the experiment.

\subsection{Establishment of Gliricidia and Leucaena Alleys and Forage Sorghum}

Gliricidia and Leucaena were sown in 2013, with a spacing of $6 \mathrm{~m}$ between double rows and $0.75 \mathrm{~m}$ between single rows and plants. The legumes were only pruned prior to the first sorghum cultivation in 2017, and the biomass that was deposited on the soil surface was composed of leaves and stems. All plots of the same treatment received the same amount of biomass, and all available dry plant residues were added to the soil, which was added according to the dry mass content shown in Table 2 . The single sorghum treatment received no plant residue.

Table 2. Macronutrient content and dry mass of plant residues deposited between lines of sorghum cultivation (double crop) in March 2017.

\begin{tabular}{|c|c|c|c|c|c|c|}
\hline Legume & $N\left(g_{k g}{ }^{-1}\right)$ & $P\left(g_{k g}-1\right)$ & $\mathrm{K}\left(\mathrm{g} \mathrm{kg}^{-1}\right)$ & $\mathrm{Ca}\left(\mathrm{g} \mathrm{kg}^{-1}\right)$ & $\operatorname{Mg}\left(\mathrm{g} \mathrm{kg}^{-1}\right)$ & Dry Mass $\left(\mathrm{Mg} \mathrm{ha}^{-1}\right)$ \\
\hline Gliricidia & 32.8 & 2.8 & 17.6 & 14.6 & 5.5 & 5.4 \\
\hline Leucaena & 33.1 & 1.7 & 11.4 & 10.5 & 3.2 & 6.0 \\
\hline
\end{tabular}

The legume biomass that was deposited in the crops was quantified using a metal frame of $0.25 \mathrm{~m}^{2}$ and dried in a forced circulation oven at $55{ }^{\circ} \mathrm{C}$ until constant weight for chemical analysis (Table 2). One month after the cutting of the alleys, the planting furrows were manually opened. Sorghum was sown on 31 March 2017, as it was characterized as double crop. Thirteen seeds per linear meter were sown, with a spacing of $0.5 \mathrm{~m}$ between rows.

After collecting data on growth, yield, leaf macronutrient levels and forage sorghum productivity of the first experiment, the area remained fallow. In 2018, the alley treatments containing Gliricidia and Leucaena were again pruned, and the residues were deposited between the rows of the subsequent single sorghum cultivation, which was characterized as a crop. The experimental procedures, the cultivar, and the amount of biomass deposited were the same as the previous year, and planting was carried out on 13 January 2018.

Planting and fertilization were only carried out in plots containing mineral fertilization with nitrogen-phosphorus-potassium (NPK), according to the requirements of the crop: $20 \mathrm{~kg} \mathrm{ha}^{-1}$ of N, 
$90 \mathrm{~kg} \mathrm{ha}^{-1}$ of $\mathrm{P}_{2} \mathrm{O}_{5}, 75 \mathrm{~kg} \mathrm{ha}^{-1}$ of $\mathrm{K}_{2} \mathrm{O}$, and $30 \mathrm{~kg} \mathrm{ha}^{-1}$ of micronutrients based on fritted trace elements (FTE) [20]. Fertilization was divided into two applications: When sorghum plants had four and seven fully expanded leaves by adding $100 \mathrm{~kg} \mathrm{ha}^{-1}$ of $\mathrm{N}$ and $75 \mathrm{~kg} \mathrm{ha}^{-1}$ of $\mathrm{K}_{2} \mathrm{O}$, respectively.

\subsection{Analysis of Plant Tissue and Sorghum Production}

When sorghum plants reached up to $50 \%$ of flowering, leaves were sampled-the fourth leaf was collected from the apex of the plants from the central rows. Eight leaves were sampled per experimental plot, and these were oven dried at $55{ }^{\circ} \mathrm{C}$ and milled in a Willey-type stationary mill for the determination of the foliar contents of $\mathrm{N}, \mathrm{P}, \mathrm{K}, \mathrm{Ca}$, and $\mathrm{Mg}$ [21].

At 85 days after sowing (DAS), eight plants of the two central rows of each plot were evaluated. Plant height and panicle length were measured from the lap of the plant up to the last expanded leaf. The stem and panicle diameters were measured using a digital caliper.

Sorghum plants were cut near the soil surface, and the plant parts were separated into stem, leaf, panicle, root, and dead material. The roots were removed with the aid of a hoe in depth of $20 \mathrm{~cm}$ and then washed under running water through a $2 \mathrm{~mm}$ sieve. Thus, the green mass of each part of the plant, as well as the leaf/stem ratio and the productivity, were obtained. The dry mass of each component was determined after drying in a forced-air oven at $55^{\circ} \mathrm{C}$ until constant weight.

\subsection{Statistical Analysis}

All results are expressed as averages \pm level of significance. The variables related to growth, production, leaf macronutrient levels, and the productivity of forage sorghum were verified for data normality by the Shapiro-Wilk test and homoscedasticity by the Bartlett test. Data were submitted to an analysis of variance and an F test, in which the averages were compared by the Tukey test at $5 \%$.

\section{Results}

There was a significant interaction between the cropping systems $(C)$ and mineral fertilization (M) for all growth variables, as well as for the dry mass of the morphological components and total sorghum production in the double crop. However, plant height (PH), panicle length (PL), and panicle dry mass (PDM) had no significant interaction between cultivation systems and mineral fertilization (Table 3). The leaf content of $\mathrm{P}$ and the sorghum yield in the double crop presented no interaction between the variables $(\mathrm{C} \times \mathrm{M})$. Moreover, the foliar contents of $\mathrm{N}, \mathrm{K}$, and $\mathrm{Mg}$ also presented no interaction $(\mathrm{C} \times \mathrm{M})($ Table 4$)$. 
Table 3. Summary of the analysis of variance of the growth components as well as the dry mass of the morphological components and total forage sorghum submitted to the combination of legume alleys and mineral fertilization.

\begin{tabular}{|c|c|c|c|c|c|c|c|c|c|c|c|}
\hline \multirow{2}{*}{$\begin{array}{c}\text { Middle Square } \\
\text { Variation Source }\end{array}$} & \multicolumn{11}{|c|}{ Double Crop } \\
\hline & PH & SD & PD & PL & LDM & SDM & PDM & DMDM & TGM & TDM & RDM \\
\hline Cultivation systems (C) & $687 *$ & $0.03 *$ & $2.5^{*}$ & $34 *$ & $318 *$ & $6573 *$ & 14,027 * & $131 *$ & $389,177 *$ & 49,341 * & $2108 *$ \\
\hline Mineral fertilization (M) & $4276 *$ & $0.24 *$ & $6.3 *$ & $89 *$ & $846^{*}$ & 27,919 * & $47,521 *$ & $632 *$ & $1,763,023$ * & 192,993 * & 37,439 * \\
\hline$(\mathrm{C} \times \mathrm{M})$ & $484 *$ & 0.008 * & $0.8^{*}$ & $12 *$ & $33 *$ & $1445^{*}$ & 2102 & 126 * & 124,341 * & $9758 *$ & $966 *$ \\
\hline \multirow[t]{2}{*}{$\mathrm{CV}(\%)$} & 8.5 & 6.7 & 11.8 & 6.9 & 12.3 & 19.7 & 27.8 & 10.6 & 17.4 & 17.7 & 29.0 \\
\hline & \multicolumn{11}{|c|}{ Crop } \\
\hline Cultivation systems (C) & $68.5 \mathrm{~ns}$ & $0.2 *$ & $0.7^{*}$ & $1.1 \mathrm{~ns}$ & 1443 * & 50,903 * & $658 \mathrm{~ns}$ & $155^{*}$ & $777,522 *$ & 81,883 * & $8905 *$ \\
\hline Mineral fertilization (M) & $16450 *$ & $1.3 *$ & 12.4 * & $150 *$ & $19,885 *$ & $793,331 *$ & $67,794 *$ & $2353 *$ & $1,590,2883$ * & $1,797,184$ * & 178,427 * \\
\hline$(\mathrm{C} \times \mathrm{M})$ & $55.1 \mathrm{~ns}$ & $0.01 *$ & $0.2 *$ & $1.2 \mathrm{~ns}$ & 841 * & $93 *$ & $1028 \mathrm{~ns}$ & $112 *$ & 82,518 * & 3378 * & 8815 * \\
\hline $\mathrm{CV}(\%)$ & 8.0 & 12.3 & 9.8 & 4.1 & 15.9 & 17.0 & 15.1 & 25.2 & 12.1 & 13.7 & 26.1 \\
\hline
\end{tabular}

Plant height (PH), stem diameter (SD), panicle diameter (PD), panicle length (PL), leaf dry mass (LDM), stem dry mass (SDM), panicle dry mass (PDM), dry mass of the dead material (DMDM), total green mass (TGM), total dry mass (TDM), and root dry mass (RDM). * = Significant at $5 \%$ probability; ns = Not significant.

Table 4. Summary of the analysis of variance of the stem leaf ratio, foliar macronutrient content, and forage sorghum yield submitted to the combination of alleys and mineral fertilization.

\begin{tabular}{|c|c|c|c|c|c|c|c|}
\hline \multirow{2}{*}{$\begin{array}{c}\text { Middle Square } \\
\text { Variation Source }\end{array}$} & \multicolumn{7}{|c|}{ Double Crop } \\
\hline & Stem/Leaf Relation & $\mathbf{N}$ & $\mathbf{P}$ & $\mathbf{K}$ & $\mathrm{Ca}$ & Mg & Yield \\
\hline Cultivation systems (C) & $0.1 *$ & $1.7^{*}$ & $0.01 \mathrm{~ns}$ & $70.3 *$ & $0.6^{*}$ & $0.5^{*}$ & $5259 *$ \\
\hline Mineral fertilization (M) & $0.2 *$ & $0.004 \mathrm{~ns}$ & $0.007 \mathrm{~ns}$ & $37.8 *$ & $0.001 *$ & $0.3^{*}$ & $123,413^{*}$ \\
\hline$(\mathrm{C} \times \mathrm{M})$ & $0.06^{*}$ & $0.05 *$ & $0.001 \mathrm{~ns}$ & 52.6 & $0.08 *$ & $0.3 *$ & 167,987 * \\
\hline \multirow[t]{2}{*}{ CV $(\%)$} & 26.8 & 7.0 & 3.4 & 12.7 & 13.3 & 21.3 & 16.4 \\
\hline & \multicolumn{7}{|c|}{ Crop } \\
\hline Cultivation systems (C) & $0.01 *$ & $85.8 *$ & $0.7^{*}$ & $0.5 \mathrm{~ns}$ & $0.5^{*}$ & $0.09 *$ & 218,755 * \\
\hline Mineral fertilization (M) & $0.19^{*}$ & $0.07 \mathrm{~ns}$ & $0.02 \mathrm{~ns}$ & $120 *$ & $0.5^{*}$ & 0.5 * & 104,247 * \\
\hline$(\mathrm{C} \times \mathrm{M})$ & $0.002 *$ & $1.4 \mathrm{~ns}$ & $0.05 *$ & $2.8 \mathrm{~ns}$ & $0.1^{*}$ & $0.006 \mathrm{~ns}$ & 443,964 * \\
\hline CV $(\%)$ & 14.3 & 10.8 & 14.3 & 9.2 & 13.8 & 15.0 & 12.2 \\
\hline
\end{tabular}

* Significant at $5 \%$ probability; ns = Not significant. 


\subsection{Sorghum Growth}

Except for the panicle diameter under the effect of the Leucaena alleys in the double crop (in which no alteration was verified), the components related to sorghum growth (plant height, stem diameter, panicle diameter and panicle length) were higher in the presence of fertilization when compared to the non-fertilized treatments (Figure 3).

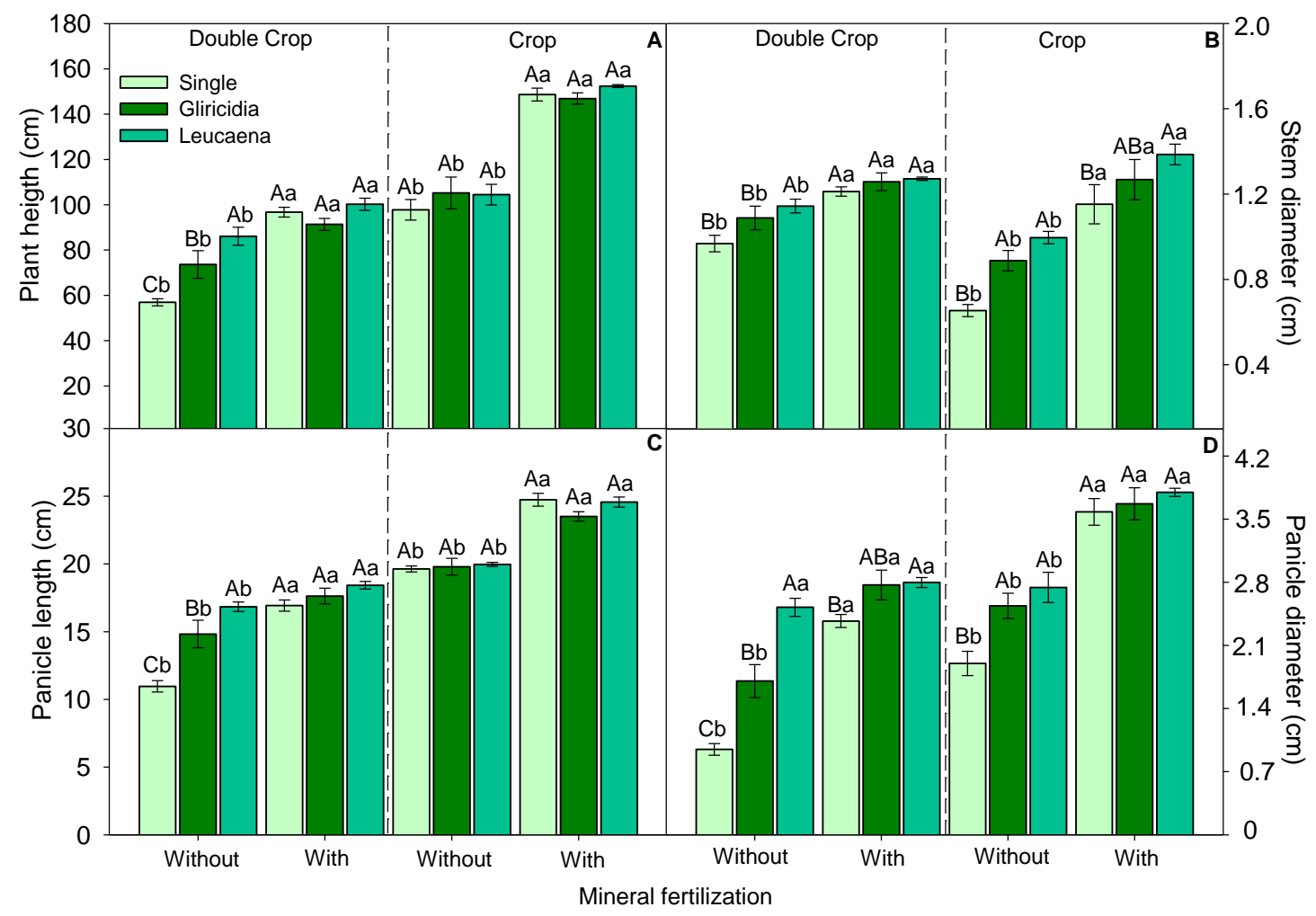

Figure 3. Plant height (A), stern diameter (B), panicle length (C) and panicle diameter (D) of forage sorghum submitted to the combination of leguminous alleys and mineral fertilization. Averages followed by the same lowercase letter for fertilization and uppercase letter for cropping systems were found by the Tukey test to not differ from each other at $5 \%$.

In the crop, the presence of Leucaena alleys increased the diameters of the stem and the panicle when compared to the single sorghum system. In the double crop, Leucaena cultivation caused more positive impacts on plant height, stem diameter, panicle diameter, and panicle length (up to $72 \%$ more than single sorghum) than in the experimental units with the presence of mineral fertilization. In the experimental units without mineral fertilization, the cultivation in Leucaena alleys was 30\% superior to the single sorghum cultivation plots in relation to plant height, stem diameter, panicle diameter and panicle length.

\subsection{Morphological Components and Biomass Production of Forage Sorghum}

In the absence of mineral fertilization, the addition of the plant residues increased the leaf dry mass (LDM) and the stem dry mass (SDM) of sorghum when compared to the single crop cultivation. This beneficial effect was verified both in the double crop and in the crop. However, there were no alterations between the cultivation systems in the presence of mineral fertilization (Figure 4). On average, leaf dry mass in alley crops exceeded the single crop by $28 \%$ and $66 \%$ in the double crop and crop, respectively. The potential of SDM production under the effect of the leguminous alleys was, on average, $100 \%$ higher than single sorghum in the double crop and crop (Figure 4). Except for 
sorghum in the double crop cultivated in Leucaena alleys, mineral fertilization increased the LDM and the SDM in relation to the treatments without fertilization.

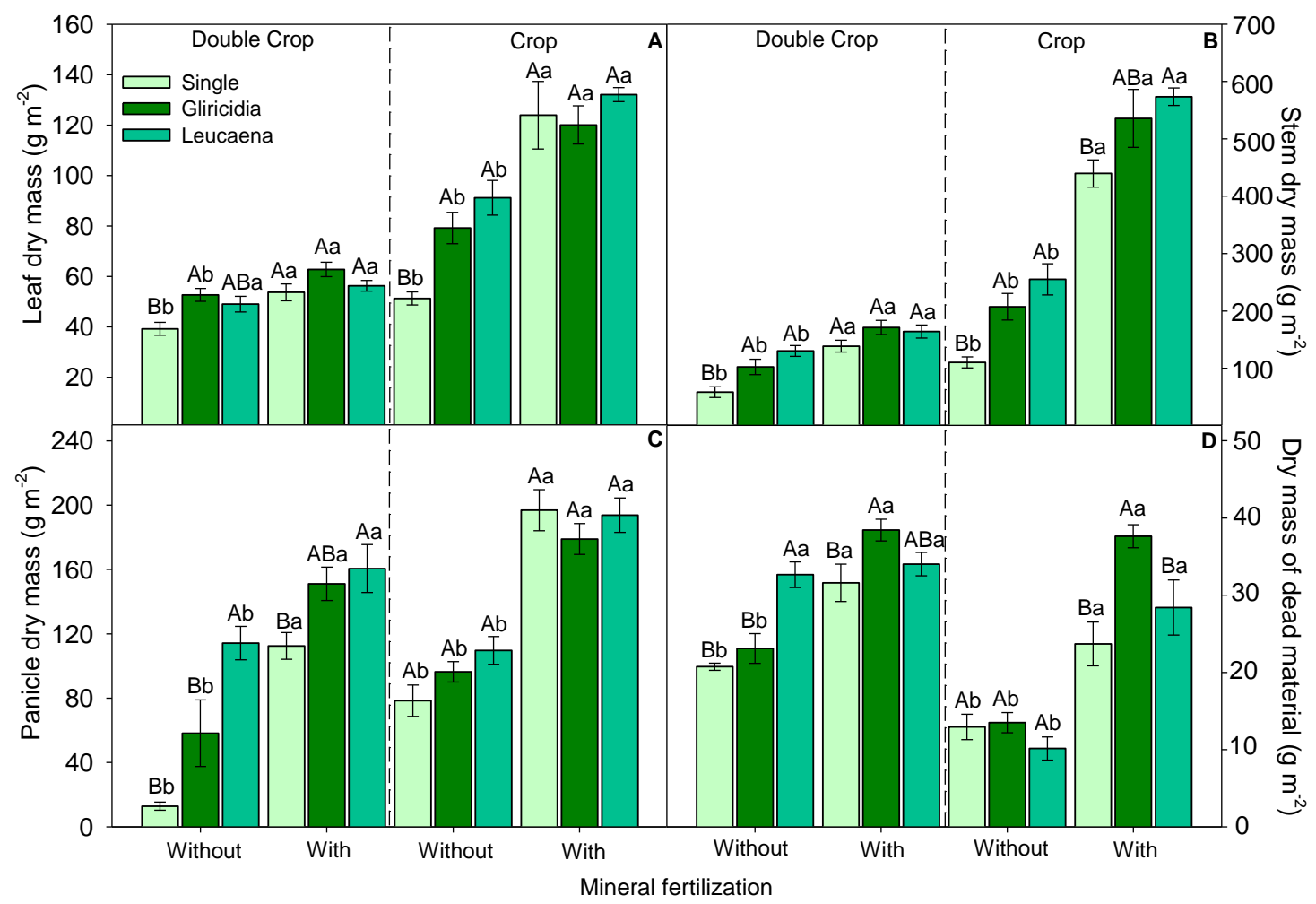

Figure 4. Leaf dry mass (A), stem dry mass (B), panicle dry mass (C), and dry mass of dead material (D) of forage sorghum submitted to the combination of leguminous alleys and mineral fertilization. Averages followed by the same lowercase letter for fertilization and uppercase letter for cropping systems were found by the Tukey test to not differ from each other at $5 \%$.

Regarding the production of the PDM in the double crop, sorghum cultivated in Leucaena alleys was much higher than single sorghum (up to 500\%). Leucaena alleys influenced the increase of the dry mass of dead material (DMDM) of sorghum cultivated without fertilization in the double crop. However, with the application of mineral fertilization, the presence of Gliricidia alleys caused an increase in the double crop and crop of $17 \%$ and $30 \%$, respectively, when compared to the single crop.

As for the total green mass (TGM) produced by sorghum in the experiment conducted during the crop, Gliricidia and Leucaena alleys without fertilization and with fertilization were $78 \%$ and $11 \%$ higher than single sorghum, respectively. In the double crop in the absence of mineral fertilization, the greater green mass production of sorghum cultivated between the alleys (up to $116 \%$ when compared to single sorghum cultivation) was also verified. Nevertheless, there was no effect of the cultivation system when mineral fertilization was applied (Figure 5). In general, the total dry mass (TDM) followed the same patterns of green mass; however, in the double crop without the application of mineral fertilization, Leucaena alleys caused more benefits to sorghum development than Gliricidia alleys. 


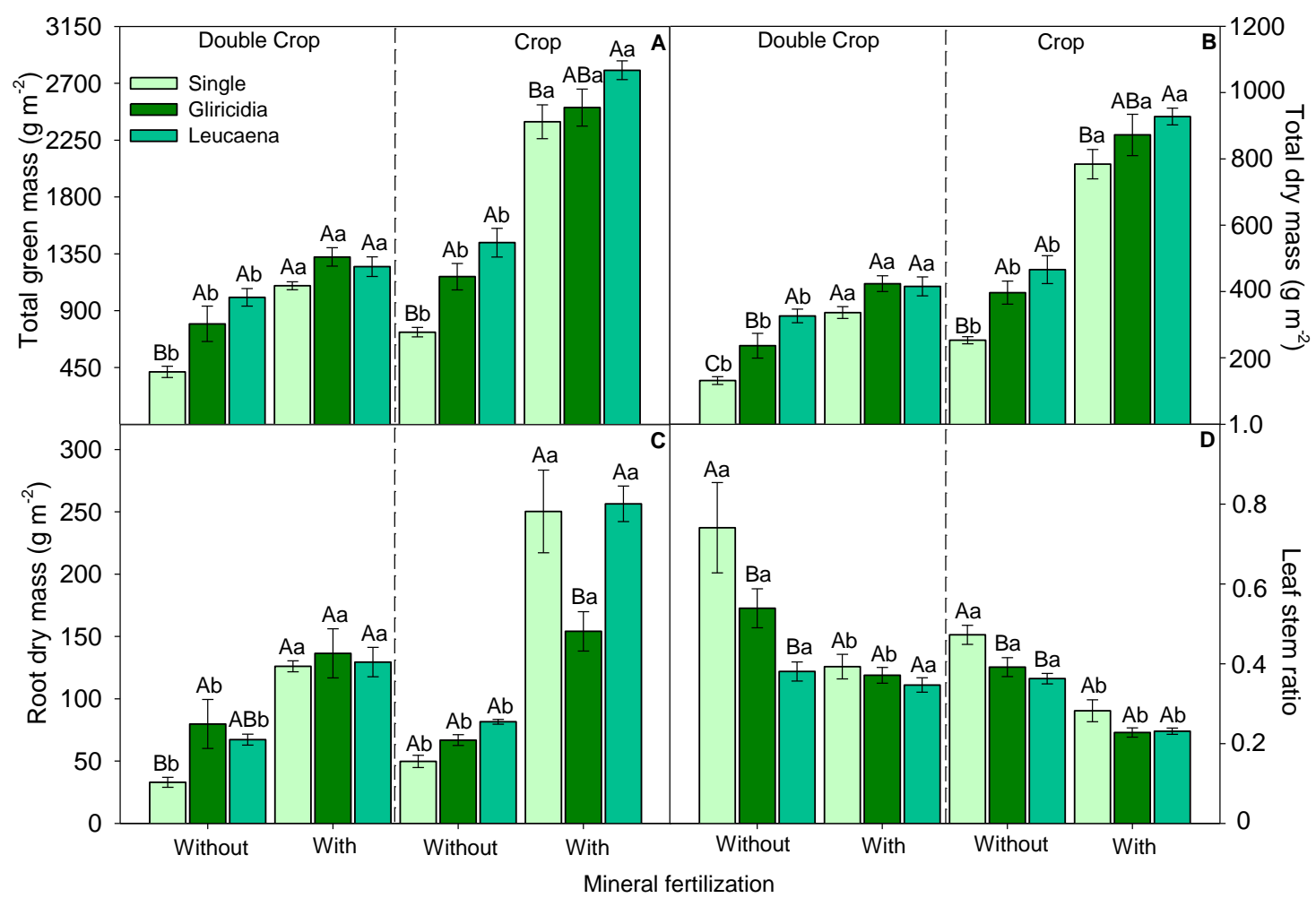

Figure 5. Total green mass (A), total dry mass (B), root dry mass (C) and forage sorghum leaf stem ratio (D) of forage sorghum submitted to the combination of leguminous alleys and mineral fertilization. Averages followed by the same lowercase letter for fertilization and uppercase letter for cropping systems were found by the Tukey test to not differ from each other at $5 \%$.

Both in the crop and in the double crop, the root dry mass (RDM) was strongly influenced by the application of mineral fertilization with an increase in root production, regardless of the cultivation system. However, in the absence of mineral fertilization in the double crop, the sorghum RDM in Gliricidia alleys exceeded single sorghum by up to $142 \%$.

The absence of mineral fertilization increased the leaf steam ratio regardless of the cultivation system. The cultivation in alleys without fertilization presented leaf stem ratios $38 \%$ and $20 \%$ lower than the single crop in the double crop and crop, respectively.

\subsection{Leaf Macronutrient Contents}

In both the double crop and in the crop, fertilization did not alter the contents of $\mathrm{N}$ and $\mathrm{P}$ in sorghum plants. However, in the crop, the cultivation of Leucaena alleys caused an increase in the contents of these nutrients when compared to the single crop (up to $28 \%$ and $26 \%$ for $\mathrm{N}$ and $\mathrm{P}$, respectively). However, in the double crop with the presence of mineral fertilization, a lower $\mathrm{N}$ content was observed under the effect of Leucaena alleys (Table 5). A lower leaf content of P also predominated under the effect of the alleys when compared to the single crop.

As for the leaf content of $\mathrm{K}$, the cultivations of the alleys without the presence of mineral fertilization in the double crop were benefited by $50 \%$ under the effect of Gliricidia and by $100 \%$ under the effect of Leucaena. However, in the crop, mineral fertilization was responsible to increase the content of $\mathrm{K}$, regardless of the cultivation system.

Gliricidia and Leucaena alley cultivation predominantly provided the lowest leaf contents of Ca and $\mathrm{Mg}$ in both the double crop and the crop when compared to the single crop. 
Table 5. Leaf macronutrients contents of forage sorghum cultivated with the combination of alleys and mineral fertilization.

\begin{tabular}{|c|c|c|c|c|c|c|c|c|c|c|c|c|c|c|c|}
\hline \multirow[t]{2}{*}{$\begin{array}{l}\text { Cultivation } \\
\text { System }\end{array}$} & \multicolumn{15}{|c|}{ Mineral Fertilization } \\
\hline & Absent & Present & Average & Absent & Present & Average & Absent & Present & Average & Absent & Present & Average & Absent & Present & Average \\
\hline & \multicolumn{3}{|c|}{$N\left(g_{k g}^{-1}\right)$} & \multicolumn{3}{|c|}{$P\left(g_{k g}^{-1}\right)$} & \multicolumn{3}{|c|}{$\mathrm{K}\left(\mathrm{g} \mathrm{kg}^{-1}\right)$} & \multicolumn{3}{|c|}{$\mathrm{Ca}\left(\mathrm{g} \mathrm{kg}^{-1}\right)$} & \multicolumn{3}{|c|}{$\operatorname{Mg}\left(\mathrm{g} \mathrm{kg}^{-1}\right)$} \\
\hline \multicolumn{16}{|c|}{ Double crop } \\
\hline Single & $7.2 \mathrm{Aa}$ & $7.3 \mathrm{Aa}$ & - & $1.6 \mathrm{Aa}$ & 1.6 Aa & $1.67 \mathrm{~A}$ & $10.8 \mathrm{Cb}$ & 17.9 Аa & - & $1.46 \mathrm{Aa}$ & $\begin{array}{c}1.26 \\
\mathrm{Ab}\end{array}$ & - & $1.2 \mathrm{Aa}$ & $0.6 \mathrm{Ab}$ & - \\
\hline Gliricidia & $6.8 \mathrm{Aa}$ & $6.7 \mathrm{ABa}$ & - & $1.5 \mathrm{Aa}$ & 1.6 Aa & $1.59 \mathrm{~B}$ & $16.2 \mathrm{Ba}$ & 18.0 Aa & - & $0.95 \mathrm{Ba}$ & $\begin{array}{c}1.1 \\
\mathrm{ABa}\end{array}$ & - & $0.7 \mathrm{Ba}$ & $0.6 \mathrm{Aa}$ & - \\
\hline Leucaena & $6.5 \mathrm{Aa}$ & $6.3 \mathrm{Ba}$ & - & $1.5 \mathrm{Aa}$ & 1.6 Aa & $1.61 \mathrm{~B}$ & $20.7 \mathrm{Aa}$ & 18.6 Aa & - & $0.81 \mathrm{Ba}$ & $0.9 \mathrm{Ba}$ & - & $0.4 \mathrm{Ca}$ & $0.5 \mathrm{Aa}$ & - \\
\hline Average & - & - & - & $1.6 \mathrm{a}$ & $1.6 \mathrm{a}$ & - & - & - & - & - & - & - & - & - & - \\
\hline \multicolumn{16}{|c|}{ Crop } \\
\hline Single & $20.9 \mathrm{Ba}$ & $20.0 \mathrm{Ba}$ & $20.5 \mathrm{~B}$ & $2.1 \mathrm{Aa}$ & $1.8 \mathrm{Ba}$ & - & $18.3 \mathrm{Ab}$ & $21.1 \mathrm{Aa}$ & $19.7 \mathrm{~A}$ & $1.4 \mathrm{Aa}$ & $1.1 \mathrm{Ab}$ & - & $0.9 \mathrm{Aa}$ & $0.6 \mathrm{Ab}$ & $0.78 \mathrm{~A}$ \\
\hline Gliricidia & $23.8 \mathrm{ABa}$ & $24.1 \mathrm{ABa}$ & $23.9 \mathrm{~A}$ & $2.0 \mathrm{Aa}$ & $2.0 \mathrm{Ba}$ & - & $16.8 \mathrm{Ab}$ & $21.7 \mathrm{Aa}$ & $19.2 \mathrm{~A}$ & $1.1 \mathrm{Ba}$ & $0.7 \mathrm{Bb}$ & - & $0.7 \mathrm{Ba}$ & $0.4 \mathrm{Bb}$ & $0.5 \mathrm{~B}$ \\
\hline Leucaena & $26.1 \mathrm{Aa}$ & $26.5 \mathrm{Aa}$ & $26.3 \mathrm{~A}$ & $2.4 \mathrm{Aa}$ & $2.49 \mathrm{Aa}$ & - & $17.3 \mathrm{Ab}$ & 21.6 Аа & $19.4 \mathrm{~A}$ & $0.8 \mathrm{Ca}$ & $0.7 \mathrm{Ba}$ & - & $0.8 \mathrm{ABa}$ & $0.5 \mathrm{ABb}$ & $0.7 \mathrm{AB}$ \\
\hline Average & $23.6 \mathrm{a}$ & $23.5 \mathrm{a}$ & - & - & - & - & $17.4 \mathrm{~b}$ & $21.4 \mathrm{a}$ & - & - & - & - & $0.8 \mathrm{a}$ & $0.5 \mathrm{~b}$ & - \\
\hline
\end{tabular}

Averages followed by the same lowercase letter within the line and uppercase letter within the column were found by the Tukey test to not differ from each other at $5 \%$. 


\subsection{Sorghum Yield}

The forage sorghum yield was improved in the crop by the mineral fertilization, regardless of the cultivation system. However, single sorghum cultivation was more dependent on fertilization than sorghum cultivated in the presence of the alleys. Single sorghum without fertilization had its productivity decreased by $62 \%$ when compared to the cropping systems with mineral fertilization in the double crop, while in the presence of the alleys, the decrease was 30\%. Regarding the cultivation of the crop the productivity decreased by $69 \%$ for single sorghum and by $48 \%$ for alley cropping.

In the crop without mineral fertilization, the crop systems presented similar productivities. However, with the presence of fertilization, single sorghum productivity increased by an average of $5500 \mathrm{~kg} \mathrm{ha}^{-1}$ when compared to cultivation in Gliricidia and Leucaena alleys (Figure 6).

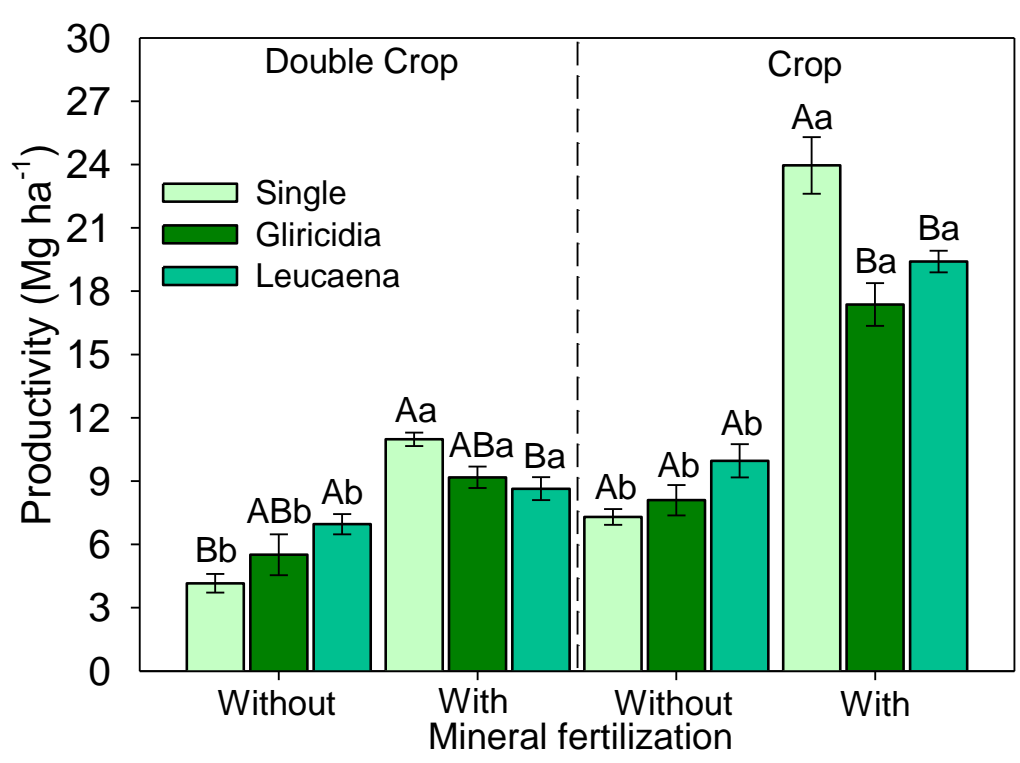

Figure 6. Productivity of forage sorghum cultivated with the combination of alleys and mineral fertilization. Averages followed by the same lowercase letter for fertilization and uppercase letter for cropping systems were found by the Tukey test to not differ from each other at $5 \%$.

In the double crop without mineral fertilization, sorghum cultivation in Leucaena alleys presented a higher productivity than the single sorghum cultivation (up to a $67 \%$ increase). With the presence of mineral fertilization, sorghum productivity in Gliricidia alleys was similar to single sorghum. Nevertheless, the cultivation in Leucaena alleys was smaller than single sorghum.

\section{Discussion}

\subsection{Morphological Components of Growth and Biomass Production of Forage Sorghum}

Plant heights, stem diameters, panicle diameters, and panicle lengths are characteristics that positively influence the production of sorghum [18]. Studies on the benefits of corn and sorghum alleys have found evidence that leguminous alleys increase plant height when compared to single cultivation [22,23]. The application of leguminous residues controls weeds and improves the physical, chemical, and biological properties of the soil [24].

The dry mass of the morphological components of the alleys was increased when compared to single sorghum, especially in the absence of mineral fertilization. The distinct characteristics of the legumes and sorghum resulted in the exploration of the different layers of the soil (as well as soil structuring and dry mass production), which is associated with a lower rate of the decomposition of residues and nutrient recycling that benefits agricultural crop [25]. 
The total green mass and the total dry mass of the alley cropping systems were higher than the single sorghum system, except in the double crop with the presence of mineral fertilization, in which the crop systems did not cause changes in these variables. Plants of the Poaceae family grown in legume alleys increase the production of green mass and dry mass when compared to conventional cultivation without alleys [26]. The most important advantages of the alley cropping system in relation to single crops are: An increased production of green and dry mass, a greater accumulation of nutrients, and soil protection [22].

When studying maize cultivation in Gliricidia alleys [13], we observed a higher total dry mass of the crop in alleys when compared to maize cultivation fertilized with manure and conventional maize cultivation. Due to their high capacity to fix atmospheric $\mathrm{N}$ and to produce biomass under conditions of low water availability, Gliricidia and Leucaena alleys are capable of improving soil fertility and increasing the dry mass production of plants in the Poaceae family [27].

The cultivation systems without the presence of mineral fertilization were similar regarding root dry mass, whereas sorghum cultivated in Gliricidia alleys was superior to the single sorghum treatment in the double crop. However, with the presence of mineral fertilization in the crop, the RDM of sorghum in Gliricidia alleys was lower than the other cropping systems, which shows that the plant did not require as much investment in roots. The production of sorghum roots may depend on competitiveness with the legumes arranged in alleys, and the longer the establishment time of the alleys, the greater the competitiveness of the legumes with the crop [5-28].

The stem leaf ratio is important for the quality of the forage. In the absence of mineral fertilization, the systems of cultivations in leguminous alleys exerted influence on sorghum development, thus resulting in lower leaf proportion and impacting the lower leaf stem ratio [29].

\subsection{Macronutrient Leaf Contents and Productivity}

The Leucaena alleys cultivation system with and without the mineral fertilization of the crop was the only one able to provide a foliar content of $\mathrm{N}$ within the critical level for the production of $80 \%$ of the crop potential [21]. However, the leaf $\mathrm{N}$ level of the double crop was low for an adequate crop production; this was related to the scarcity of rain, which caused a limited $\mathrm{N}$ availability to the plants [30].

When studying Gliricidia and Leucaena alleys as a way to improve soil properties, Fernandes et al. [27] found that the residues incorporated 160 and $130 \mathrm{~kg} \mathrm{ha}^{-1}$ year $^{-1}$ of N, respectively (when only considering $\mathrm{N}$ ). The leguminous alleys recovered about $20 \%$ of $\mathrm{N}$ directly from the residues deposited in the soil [11-16]. BNF can also represent $\mathrm{N}$ inputs relevant to the soil/plant system and reduce the need for $\mathrm{N}$ fertilizer application, which is often expensive and most susceptible to losses [8].

In the experiment developed during the crop of 2017/2018, the cultivation in alleys was superior when to that of the single crop for $\mathrm{N}$ leaf content. [30,31] found that leguminous alleys could increase the efficiency of $\mathrm{N}$ fertilizer use. However, in the present study, mineral fertilization did not influence the leaf $\mathrm{N}$ content of the crop.

In the present study, Leucaena alley cropping was the only system that increased the leaf concentration of $\mathrm{N}$ in sorghum, thus contributing to an increase of $28 \%$. When studying maize cultivation in Gliricidia alleys [12], we found an increase of $86 \%$ of $\mathrm{N}$ of the particulate organic matter of the soil in relation to the cultivation of single maize, which was compared to the effect of the use of $50 \mathrm{~kg} \mathrm{ha}^{-1}$ of $\mathrm{N}$ fertilizer.

As for the content of leaf $\mathrm{P}$, the crop cultivation systems were adequate, except for single sorghum with mineral fertilization. However, in the double crop, even with the presence of mineral fertilization, the P levels of the cropping systems were below the ideal for the sorghum crop [19]. De Paula et al. [32] found that $\mathrm{P}$ from the decomposition of leguminous residues formed less water-soluble compounds and moved more slowly from one compartment to another. Furthermore, the half-life of nutrient release is shorter in the double crop. 
The foliar content of $\mathrm{P}$ of the double crop and crop did not change with the mineral fertilization factor. [33] pointed out that BNF carried out by legumes results in higher energy and P expenditure by legumes. However, in the crop of 2017/2018, sorghum cultivated in Leucaena alleys with mineral fertilization showed a higher leaf content of $\mathrm{P}$ when compared to the other cropping systems. Nevertheless, there were no alterations between crop systems without mineral fertilization.

In a nutritional study of corn intercropped with legumes, the authors of [26] found changes in leaf $\mathrm{P}$ content only in the second year, in which this content was higher in legume crops than the conventional treatment. Thus, several plant species, especially perennial legumes, can use non-labile fractions of $\mathrm{P}$ by modifying the chemistry of their rhizosphere, excreting protons and organic acids to solubilize $P$ and leave it available for crops [34].

The content of $\mathrm{K}$ remained adequate in all cropping systems in the two years of cultivation, regardless of the mineral fertilization, except for the single sorghum cultivation without mineral fertilization of the double crop, which presented a K content below suitable levels for the crop [21].

In the legume alley cropping without the mineral fertilization of the double crop, the content of leaf $\mathrm{K}$ was higher than that of the single crop. However, with the presence of mineral fertilization, the crop systems were similar. These results indicate that, in addition to providing nutrients from the plant residues to the main crop, these legumes probably recycled $\mathrm{K}$ from depths beyond the crop zone by sorghum roots $[35,36]$.

The cropping systems did not undergo alterations regarding the foliar content of $K$, either with fertilization or without fertilization. Since the crop experiment was implemented in the second cycle, there is evidence that the content of $\mathrm{K}$ originating from the first cycle was sufficient and altered the effect in the double crop cycle [33]. The authors of [37] stated that in the cultivation of maize in alleys, legumes positively increased the content of leaf $\mathrm{K}$ in maize from the first crop cycle, which was similar to the conventional cultivation.

As for the levels of $\mathrm{Ca}$ and $\mathrm{Mg}$, they were inadequate in all treatments-both in the double crop and in the crop [21]. Regardless of mineral fertilization, the lowest foliar contents of Ca and Mg were verified in the presence of leguminous alley crops. This result denotes the existence of competition between the legumes and the sorghum crop. However, the competition increases with the presence of mineral fertilization in the crop. The legume species require the same resources as the associated crops, which can result in both complementarity and competition [5].

Legumes have deep roots, can intercept percolated nutrients along the soil profile, and can access nutrients accumulated in the layers below the root zone of annual crops. These nutrients absorbed by the root system of the trees become inputs in the form of plant residues [10]. In general, legume residues provide $\mathrm{Ca}$ and $\mathrm{Mg}$ for agricultural crops. However, the slow release of these nutrients is probably due to the fact that they are some of the constituents of the middle lamella of the cell wall, forming one of the most recalcitrant components of the tissues [28-38].

On average, the presence of mineral fertilization in the cropping systems doubled the productivity in the two years of experiment. The leguminous alleys of the crop without mineral fertilization showed results similar to single sorghum cultivation. As for the presence of mineral fertilization, the systems of cultivation in leguminous alleys were smaller than the single sorghum cultivation.

Akinnifesi et al. [30] reported that corn yield in Gliricidia alleys without the mineral fertilization of $\mathrm{N}$ and $\mathrm{P}$ was $39 \%$ higher than in the single maize plots that received the recommended total amounts of N and P. When the Gliricidia alleys were altered with $50 \% \mathrm{~N}$ and $100 \% \mathrm{P}$, the yield increased by $79 \%$.

Crops in legume alleys presented a surface area 30\% lower than the single crop. In a study that related sorghum cultivation to leguminous alleys, the authors of [39] pointed out that the yield of sorghum cultivated in leguminous alleys corresponded to $94 \%$ in relation to conventional cultivation, although $86 \%$ of the area was occupied in the system.

The cultivation in leguminous alleys denotes its importance as a practice of agriculture with low external input as a form of soil fertilization, because it can maintain or increase the productive capacity of integrated agricultural crops [33]. Leguminous alleys are important for the morphological 
development, growth, biomass production, and nutrition components of forage sorghum, especially $\mathrm{N}$. In the present study, sorghum yield was increased and presented a direct relation with the presence of the alleys.

\section{Conclusions}

The presence of mineral fertilization improved the results of all studied cultivation systems (single sorghum, sorghum grown in Leucaena alleys and sorghum grown in Gliricidia alleys) when compared to the absence of fertilization. Nevertheless, the cultivation in alleys was not significantly different when considering the influence of mineral fertilization on plant height, panicle length, leaf dry mass, leaf stem ratio and the leaf content of $\mathrm{K}$ in both experimental periods. Leucaena alleys outperformed Gliricidia alleys considering plant height, panicle diameter and panicle length. At least one of the alley cropping systems was larger than the single sorghum for the dry mass of the morphological components, total yield of green mass, and dry and root mass.

The contents of leaf $\mathrm{N}$ and $\mathrm{P}$ were not related to mineral fertilization. The alleys were able to positively influence the contents of these nutrients in the plant. The cultivation in Leucaena alleys increased the content of $\mathrm{P}$ when compared to single sorghum in the crop. The cultivation of sorghum in the alley cropping system also contributed to a higher leaf content of $\mathrm{K}$ when compared to the single crop in the double crop. The leguminous plants could have competed with sorghum for $\mathrm{Ca}$ and $\mathrm{Mg}$, resulting in lower levels of these elements when compared to the single crop.

Mineral fertilization increased sorghum productivity regardless of the studied cultivation system. Gliricidia and Leucaena alleys showed clear potential to increase sorghum productivity, especially for sorghum cultivated in the double crop. However, in the crop with the presence of mineral fertilization, the cultivation in alleys did not overcome single sorghum cultivation regarding productivity.

Author Contributions: Conceptualization, R.d.C.L. (Robson da Costa Leite) and A.C.d.S.; methodology, R.d.C.L. (Robson da Costa Leite), R.d.C.L. (Rubson da Costa Leite) and A.C.d.S.; software, R.d.C.L. (Robson da Costa Leite), L.F.S. and L.F.R.; validation, A.C.d.S., J.G.D.d.S. and L.F.S.; data curation, R.d.C.L. (Robson da Costa Leite), G.O.d.S.S., J.S.d.S.C. and R.d.C.L. (Rubson da Costa Leite); writing-original draft preparation, R.d.C.L. (Robson da Costa Leite); writing — review and editing, R.d.C.L. (Robson da Costa Leite) and J.G.D.d.S.; supervision; A.C.d.S.

Funding: This study was carried out with the support of the Coordination of Improvement of Higher Education Personnel-Brazil (CAPES)-Financing Code 001.

Conflicts of Interest: The authors declare no conflict of interest.

\section{References}

1. EMBRAPA (Empresa Brasileira de Pesquisa Agropecuária). Sistema Brasileiro de Classificação de Solos, 3rd ed.; Centro Nacional de Pesquisa de Solos: Brasília, Brazil, 2013; p. 353.

2. Ekepu, D.; Tirivanhu, P. Assessing socio-economic factors influencing adoption of legume-based multiple cropping systems among smallholder sorghum farmers in Soroti, Uganda. S. Afr. J. Agric. Ext. (SAJAE) 2016, 44, 195-215. [CrossRef]

3. Omari, R.A.; Aung, H.P.; Hou, M.; Yokoyama, T.; Onwona-Agyeman, S.; Oikawa, Y.; Fujii, Y.; Bellingrath-Kimura, S.D. Influence of Different Plant Materials in Combination with Chicken Manure on Soil Carbon and Nitrogen Contents and Vegetable Yield. Pedosphere 2016, 26, 510-521. [CrossRef]

4. Williams, D.M.; Blanco-Canqui, H.; Francis, C.A.; Galusha, T.D. Organic Farming and Soil Physical Properties: An Assessment after 40 Years. Agron. J. 2017, 109, 600. [CrossRef]

5. Marin, A.M.P.; Menezes, R.S.C.; Salcedo, I.H. Produtividade de milho solteiro ou em aléias de gliricídia adubado com duas fontes orgânicas. Pesquisa Agropecuária Brasileira 2007, 42, 669-677. [CrossRef]

6. Oliveira, F.R.A.D.; Souza, H.A.D.; Carvalho, M.A.R.D.; Costa, M.C.G. Green fertilization with residues of leguminous trees for cultivating maize in degraded soil. Rev. Caatinga 2018, 31, 798-807. [CrossRef]

7. De Moura, E.G.; Albuquerque, J.M.; Aguiar, A.D.C.F. Growth and productivity of corn as affected by mulching and tillage in Alley cropping systems. Sci. Agricola 2008, 65, 204-208. [CrossRef] 
8. Martins, J.C.R.; Freitas, A.D.S.D.; Menezes, R.S.C.; Sampaio, E.V.D.S.B. Nitrogen symbiotically fixed by cowpea and gliricidia in traditional and agroforestry systems under semiarid conditions. Pesquisa Agropecuária Brasileira 2015, 50, 178-184. [CrossRef]

9. De Oliveira, V.R.; E Silva, P.S.L.; Pontes, F.S.T.; De Paiva, H.N.; Antonio, R.P. Growth Of Arboreal Leguminous Plants And Maize Yield In Agroforestry Systems. Revista Árvore 2016, 40, 679-688. [CrossRef]

10. Loss, A.; Pereira, M.G.; Ferreira, E.P.; Dos Santos, L.L.; Beutler, S.J.; Júnior, A.S.D.L.F. Frações oxidáveis do carbono orgânico em argissolo vermelho-amarelo sob sistema de aleias. Revista Brasileira de Ciência do Solo 2009, 33, 867-874. [CrossRef]

11. Aguiar, A.D.C.F.; Amorim, A.P.; Coelho, K.P.; De Moura, E.G. Environmental and agricultural benefits of a management system designed for sandy loam soils of the humid tropics. Revista Brasileira de Ciência do Solo 2009, 33, 1473-1480. [CrossRef]

12. Beedy, T.; Snapp, S.; Akinnifesi, F.; Sileshi, G. Impact of Gliricidia sepium intercropping on soil organic matter fractions in a maize-based cropping system. Agric. Ecosyst. Environ. 2010, 138, 139-146. [CrossRef]

13. Primo, D.C.; Menezes, R.S.C.; Sampaio, E.V.D.S.B.; Garrido, M.D.S.; Junior, J.C.B.D.; Souza, C.S. Recovery of $\mathrm{N}$ applied as $15 \mathrm{~N}$-manure or $15 \mathrm{~N}$-gliricidia biomass by maize, cotton and cowpea. Nutr. Cycl. Agroecosyst. 2014, 100, 205-214. [CrossRef]

14. Primo, D.; Menezes, R.; Filho, R.; Dutra, E.; Silva, E.; Alves, R.; Sampaio, E.; Antonino, A.; Lucena, E. Characteristics Physico-Chemical and Carbon Balance in Fluvic Entisol after Six Years Fertilization with Manure and Gliricidia. J. Exp. Agric. Int. 2018, 23, 1-11. [CrossRef]

15. Moura-Silva, A.G.; Aguiar, A.D.C.F.; Jorge, N.; Agostini-Costa, T.D.S.; Moura, E.G. Food quantity and quality of cassava affected by leguminous residues and inorganic nitrogen application in a soil of low natural fertility of the humid tropics. Bragantia 2017, 76, 406-415. [CrossRef]

16. Mundus, S.; Menezes, R.S.C.; Neergaard, A.; Garrido, M.S. Maize growth and soil nitrogen availability after fertilization with cattle manure and/or gliricidia in semi-arid NE Brazil. Nutr. Cycl. Agroecosyst. 2008, 82, 61-73. [CrossRef]

17. Calvo, C.L.; Foloni, J.S.S.; Brancalião, S.R. Produtividade de fitomassa e relação C/N de monocultivos e consórcios de guandu-anão, milheto e sorgo em três épocas de corte. Bragantia 2010, 69, 77-86. [CrossRef]

18. De Oliveira, L.B.; Pires, A.J.V.; Viana, A.E.S.; Matsumoto, S.N.; De Carvalho, G.G.P.; Ribeiro, L.S.O. Produtividade, composição química e características agronômicas de diferentes forrageiras. Revista Brasileira de Zootecnia 2010, 39, 2604-2610. [CrossRef]

19. Alvares, C.A.; Stape, J.L.; Sentelhas, P.C.; Gonçalves, J.L.D.M.; Sparovek, G. Köppen's climate classification map for Brazil. Meteorol. Z. 2013, 22, 711-728. [CrossRef]

20. Sousa, D.M.G.; Lobato, E. Cerrado: Correção do Solo E Adubação, 2nd ed.; Embrapa Cerrados: Brasília, Brazil, 2004; p. 416.

21. Boaretto, A.E.; van Raij, B.; da Silva, F.C.; Chitolina, J.C.; Tedesco, M.J.; do Carmo, C.A.F. Amostragem acondicionamento e preparo de amostras de planta para análise química. In Manual de Análises Químicas de Solos, planta e fertilizantes; da Silva, F.C., Ed.; Embrapa informação tecnológica: Brasília, Brazil, 2009; pp. 61-85.

22. Andrade Neto, R.C.; Miranda, N.O.; Duda, G.P.; Góes, G.B.; Lima, A.S. Crescimento e produtividade do sorgo forrageiro BR 601 sob adubação verde. Revista Brasileira de Engenharia Agrícola e Ambiental 2010, 14, 124-130. [CrossRef]

23. Silva, A.R.D.; Collier, L.S.; Flores, R.A.; Santos, V.M.D.; Silva, L.L.D.; Oliveira, V.A.; Barbosa, J.M. Productive Yield of Cowpea and Maize in Single Crop and Mixtures in an Agroforestry System. Am. Eur. J. Agric. Environ. Sci. 2015, 15, 85-92.

24. Silva, P.S.L.; Oliveira, V.R.D.; Silva, P.I.B.; Chicas, L.D.S.; Tomaz, F.L.D.S. Effects of ground cover from branches of arboreal species on weed growth and maize yield. Revista Ciência Agronômica 2015, 46, 809-817. [CrossRef]

25. De Carvalho, W.P.; De Carvalho, G.J.; Neto, D.D.O.A.; Teixeira, L.G.V. Desempenho agronômico de plantas de cobertura usadas na proteção do solo no período de pousio. Pesquisa Agropecuária Brasileira 2013, 48, 157-166. [CrossRef]

26. Heinrichs, R.; Vitti, G.C.; Moreira, A.; Fancelli, A.L. Produção e estado nutricional do milho em cultivo intercalar com adubos verdes. Revista Brasileira de Ciência do Solo 2002, 26, 225-230. [CrossRef] 
27. Fernandes, M.F.; Barreto, A.C. Cultivo de Gliricidia sepium e Leucaena leucocephala em alamedas visando a melhoria dos solos dos tabuleiros costeiros. Pesquisa Agropecuária Brasileira 2001, 36, 1287-1293.

28. Martins, J.C.R.; Menezes, R.S.C.; Sampaio, E.V.S.B.; Dos Santos, A.F.; Nagai, M.A. Produtividade de biomassa em sistemas agroflorestais e tradicionais no Cariri Paraibano. Revista Brasileira de Engenharia Agrícola e Ambiental 2013, 17, 581-587. [CrossRef]

29. Gama, T.D.C.M.; Volpe, E.; Lempp, B.; Galdeia, E.C. Recuperação de pasto de capim-braquiária com correção e adubação de solo e estabelecimento de leguminosas. Revista Brasileira de Saúde e Produção Animal 2013, 14, 635-647. [CrossRef]

30. Akinnifesi, F.K.; Makumba, W.; Sileshi, G.; Ajayi, O.C.; Mweta, D. Synergistic effect of inorganic N and P fertilizers and organic inputs from Gliricidia sepium on productivity of intercropped maize in Southern Malawi. Plant Soil 2007, 294, 203-217. [CrossRef]

31. Chirwa, P.W.; Black, C.R.; Ong, C.K.; Maghembe, J. Nitrogen Dynamics in Cropping Systems in Southern Malawi Containing Gliricidia sepium, Pigeonpea and Maize. Agrofor. Syst. 2006, 67, 93-106. [CrossRef]

32. De Paula, P.D.; Campello, E.F.C.; Guerra, J.G.M.; Santos, G.D.A.; De Resende, A.S. DECOMPOSIÇÃO DAS PODAS DAS LEGUMINOSAS ARBÓREAS Gliricidia sepium E Acacia angustissima EM UM SISTEMA AGROFLORESTAL. Ciência Florest. 2015, 25, 791-800. [CrossRef]

33. Queiroz, L.R.; Coelho, F.C.; Barroso, D.G.; Galvão, J.C.C. Cultivo de milho consorciado com leguminosas arbustivas perenes no sistema de aléias com suprimento de fósforo. Rev. Ceres. 2008, 55, 409-415.

34. Hauggaard-Nielsen, H.; Jensen, E.S. Facilitative Root Interactions in Intercrops. Plant Soil 2005, 274, $237-250$. [CrossRef]

35. Makumba, W.; Janssen, B.; Oenema, O.; Akinnifesi, F.; Mweta, D.; Kwesiga, F. The long-term effects of a gliricidia-maize intercropping system in Southern Malawi, on gliricidia and maize yields, and soil properties. Agric. Ecosyst. Environ. 2006, 116, 85-92. [CrossRef]

36. Primo, D.C.; Menezes, R.S.C.; Oliveira, F.F.D.; Dubeux Júnior, J.C.B.; Sampaio, E.V.S.B. Timing and placement of cattle manure and/or gliricidia affects cotton and sunflower nutrient accumulation and biomass productivity. Anais da Academia Brasileira de Ciências 2018, 90, 415-424. [CrossRef] [PubMed]

37. De Moura, E.G.; Serpa, S.S.; Dos Santos, J.G.D.; Sobrinho, J.R.S.C.; Aguiar, A.D.C.F. Nutrient use efficiency in alley cropping systems in the Amazonian periphery. Plant Soil 2010, 335, 363-371. [CrossRef]

38. Taiz, L.; Zeiger, E.; Moller, I.; Murphy, A. Fisiologia e Desenvolvimento Vegetal, 6th ed.; Artmed: Porto Alegre, Brazil, 2017; p. 888.

39. Korwar, G.R. Fodder production potential of leucaena hedgerows on an Alfisol and a Vertisol in the semi-arid tropics. In Proceedings of the International Workshop on Nitrogen Fixing Trees for Fodder Production, Morillion, AR, USA, 20-25 March 1995; pp. 146-153. 